\title{
Gluten til spedbarn gir verken mer eller mindre cøliaki
}

\author{
Daglig inntak av gluten i spedbarnsalder reduserer ikke risikoen for \\ å utvikle cøliaki før treårsalder.
}

Cøliaki forekommer hos $1-3 \%$ av befolkningen og hos $10 \%$ av dem som har førstegradsslektninger med cøliaki. Sykdommen er sterkt assosiert med vevstypeantigenene HLA-DQ2 eller HLA-DQ8, som imidlertid finnes hos en firedel av normalbefolkningen. Dette tyder på at også miljøfaktorer har

betydning for utviklingen av cøliaki. Kan risikoen for cøliaki reduseres dersom gluten blir introdusert i kosten i 4-6 måneders alder, slik noen studier tyder på?

I en randomisert studie som nylig er publisert i New England Journal of Medicine deltok nesten 1000 spedbarn med minst én

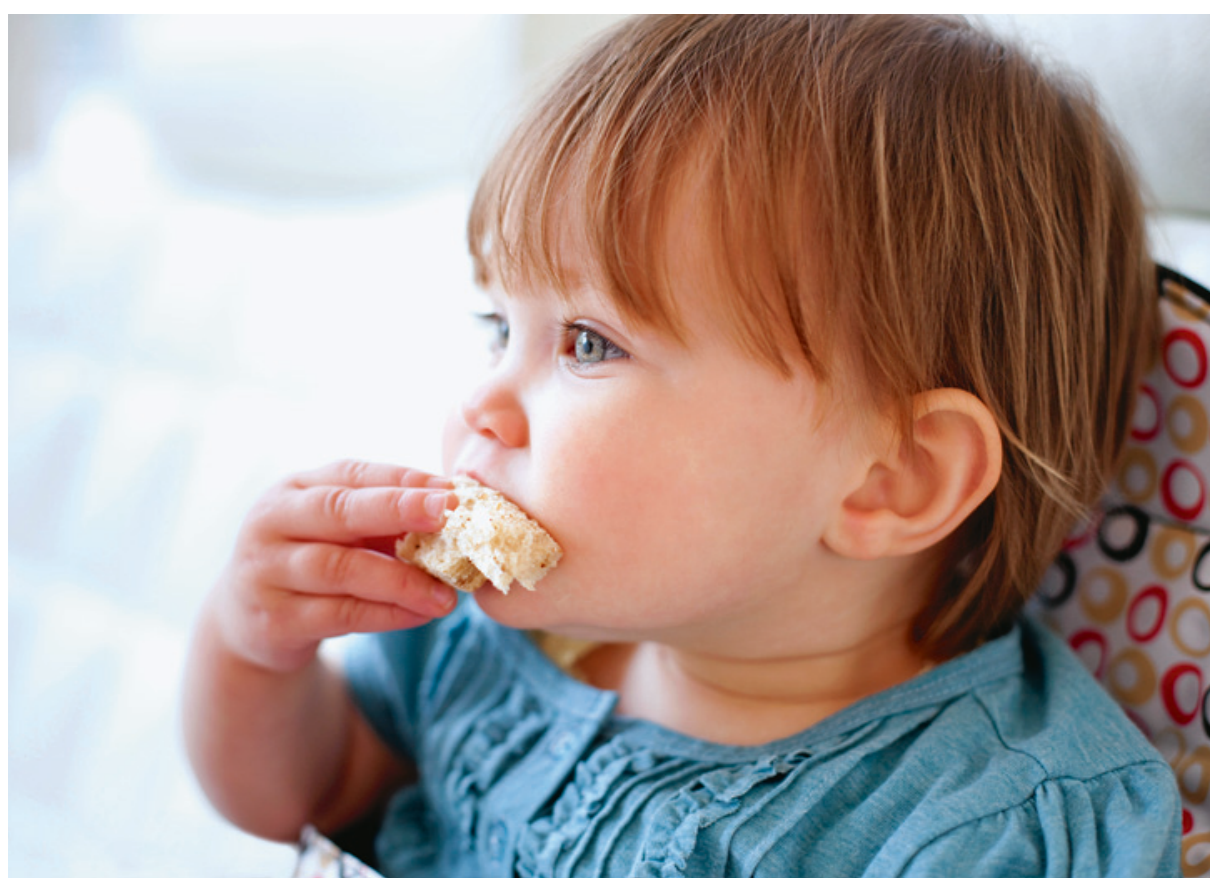

Illustrasjonsfoto: Science Photo Library/NTB scanpix førstegradsslektning med cøliaki og med vevstypene HLA-DQ2 eller HLA-DQ8 (1). Fra 16-24 ukers alder fikk om lag halvparten av barna $100 \mathrm{mg}$ gluten daglig, mens resten fikk placebo. Ved treårsalder var det ingen signifikante forskjeller i utviklingen av cøliaki i de to gruppene. Det var heller ingen signifikante forskjeller $\mathrm{i} ø \mathrm{kning}$ av antistoffer mot transglutaminase-2 eller gliadin. Det var ingen beskyttende effekt av amming for dem som fikk gluten.

- Denne studien tar utgangspunkt i observasjoner fra den «svenske epidemien» $i$ 1980-årene der det ble spekulert på om manglende amming og/eller utsatt introduksjon av gluten kunne forklare økt forekomst av cøliaki blant små barn, forteller Knut E. A. Lundin, som er overlege ved Seksjon for fordøyelsessykdommer ved Oslo universitetssykehus og førsteamanuensis ved Universitetet i Oslo.

- Epidemiologiske studier fra USA og Norge har vist en sammenheng mellom introduksjon av gluten før fire eller etter seks måneders alder og risiko for cøliaki. I denne studien finner man imidlertid ikke støtte for dette. Den viktigste svakheten med studien er at man brukte en lav dose gluten, som bare er $2 \%$ av naturlig inntak. Det kan hende at en høyere dose ville gitt et annet resultat, sier Lundin.

\section{Lise Mørkved Helsingen \\ Tidsskriftet}

Litteratur

1. Vriezinga SL, Auricchio R, Bravi E et al. Randomized feeding intervention in infants at high risk for celiac disease. N Engl J Med 2014; 371: 1304-15.

\section{Tyreoidektomi eller lobektomi ved thyreoideakreft?}

\section{Det var ingen forskjell i overlevelse etter henholdsvis tyreoidektomi og lobektomi ved papillær thyreoidea- kreft i en ny amerikansk register- studie.}

Papillær thyreoideakreft utgjør om lag $90 \%$ av alle tilfeller av thyreoideakreft, og over $90 \%$ av pasientene lever lenger enn 20 år etter kirurgisk behandling. I mange retningslinjer anbefales total tyreoidektomi fremfor lobektomi når tumor er $>1 \mathrm{~cm}$, men det er usikkert om dette har betydning for prognosen etter operasjon (1).

En retrospektiv registerstudie fra USA omfattet nesten 62000 pasienter med papillær thyreoideakreft der tumor var 1,0-4,0 cm stor. Rundt 55000 ble behandlet med total tyreoidektomi og rundt 7000 med lobektomi. Den første gruppen hadde generelt mer utbredt sykdom, men etter median sju år var det ingen forskjell i overlevelse mellom gruppene (hasardratio 0,96; 95 KI 0,84-1,09). Høy alder, mann, afroamerikansk rase, lav inntekt, tumorstørrelse og metastaser var signifikant assosiert med lavere overlevelse.

- Overlevelsen etter operasjon for papillær thyreoideakreft er god - derfor må man være spesielt oppmerksom på over- og underbehandling, sier Jan Erik Varhaug, som er professor emeritus ved Universitetet i Bergen. - Studien sier ikke noe om morbiditet, men gjentatte residiver kan kreve en rekke inngrep med forhøyet komplikasjonsrisiko. Derfor kan totalbelastningen for pasientene være betydelig høyere enn over- levelsen alene gir inntrykk av. Residiv etter primærbehandling kan komme over 20 år etterpå, sier Varhaug.

- Valg av operasjonsmetode bør ikke baseres på retrospektive registerdata alene, men på en samlet vurdering av bl.a. tumorstørrelse, lymfeknuter, histologisk type og risiko for komplikasjoner. I Norge er behandlingen av thyreoideakreft sentralisert, og nye retningslinjer for utredning og behandling er snart ferdige, sier Varhaug.

\section{Lise Mørkved Helsingen}

Tidsskriftet

\section{Litteratur}

1. Adam MA, Pura J, Gu L et al. Extent of surgery for papillary thyroid cancer is not associated with survival: an analysis of 61,775 patients. Ann Surg 2014; 260 : $601-5$ 